\title{
STRUKTUR VEGETASI MANGROVE BERDASARKAN KUALITAS LINGKUNGAN BIOFISIK DI TAMAN HUTAN RAYA NGURAH RAI BALI
}

\author{
Ajie Imamsyah*, Dietriech Geoffrey Bengen, Meutia Samira Ismet \\ Departemen Ilmu dan Teknologi Kelautan, Fakultas Perikanan dan Ilmu Kelautan, Institut Pertanian \\ Bogor \\ "Email: ajieimamsyah21@gmail.com
}

\begin{abstract}
STRUCTURE OF MANGROVE VEGETATION BASED ON BIOPHYSICAL ENVIRONMENTAL QUALITY IN NGURAH RAI FOREST PARK BALI
\end{abstract}

Mangroves are typical coastal plants whose habitat is influenced by tidal and substrate characteristics. Mangrove ecosystems have a variety of functions that can be utilized both in terms of physical, biological, and economic. Utilization of mangrove ecosystems that do not pay attention to environmental sustainability and conservation aspects cause damage of a whole coastal ecosystems. This study aims to analyze the structure of mangrove vegetation based on biophysical environment quality. This research was conducted on February until March 2017 at Ngurah Rai Forest Park Bali. The results of study show that the conditions of temperature, $\mathrm{pH}$, and salinity are still in accordance with the specified quality standards, however dissolved oxygen has been classified as polluted by anthropogenic waste. The analysis of the structure and distribution of mangrove vegetation found that species of $S$. alba dominated at the location research, followed by $R$. apiculata, $R$. mucronata, B. gymnorrhiza, $R$. stylosa, X. granatum, A. marina, and $A$. corniculatum. Overall, the mangrove condition was damaged category with a mangrove density value $<1000 \mathrm{ind} / \mathrm{ha}$.

Keywords: Coastal; Environmental; Mangrove; Vegetation

\section{PENDAHULUAN}

Ekosistem pesisir adalah ekosistem peralihan antara darat dan laut dimana terdapat ekosistem penunjang kehidupan organisme seperti ekosistem terumbu karang, padang lamun, dan mangrove. Selain untuk penunjang kehidupan organisme laut, ekosistem pesisir juga memiliki peran vital secara fisik yaitu melindungi pantai dari gelombang pasang, erosi, dan abrasi. Secara ekonomis, ekosistem pesisir juga dapat dimanfaatkan sebagai penghasil sumberdaya dan produktivitas hayati yang bernilai ekonomis tinggi, penyedia jasa lingkungan, dan kawasan ekowisata. Namun adanya pemanfaatan ekosistem secara berlebihan ditengarai akan menyebabkan perubahan ekosistem pesisir, salah satunya adalah ekosistem mangrove.

Mangrove adalah tumbuhan khas yang tumbuh di pantai dan estuari serta tergenang oleh pasang surut air laut. Ekosistem mangrove dapat dikatakan bersifat kompleks, dinamis, dan labil. Dikatakan kompleks karena ekosistem mangrove merupakan habitat monyet, ular, burung, dan organisme perairan. Dikatakan dinamis karena adaptif terhadap kondisi lingkungan dan bersifat labil karena rentan rusak dan memerlukan waktu yang lama untuk mengembalikan fungsi ekosistem (Ashton et al., 2003). Ekosistem mangrove termasuk ekosistem dengan keanekaragaman hayati dengan berbagai macam fungsi baik secara fisik, biologis, dan ekonomis. Di samping itu, ekosistem mangove juga dimanfaatkan oleh organisme 
laut untuk memulai rantai makanan dengan memanfaatkan serasah mangrove. Tidak hanya organisme laut, masyarakat juga seringkali memanfaatkan areal mangrove sebagai tambak, kayu bakar, bahan obat obatan, dan lainnya.

Kondisi ekosistem mangrove sebagai habitat berbagai macam organisme kini eksistensinya terancam. Seiring bertambahnya jumlah penduduk dan ditambah dengan meningkatnya kebutuhan sehari - hari, ditengarai akan membuat ekosistem mangrove perlahan kehilangan perannya sebagai penyangga ekosistem pesisir. Hal ini juga didukung dengan adanya pemanfaatan ekosistem mangrove yang tidak melihat dari aspek kelestarian lingkungan dan konservasi seperti yang terjadi di Taman Hutan Raya (Tahura) Ngurah Rai Bali.

Kawasan Tahura Ngurah Rai Bali merupakan habitat ekosistem mangrove terluas di Bali yang terletak di Kabupaten Badung dan Kota Denpasar. Kawasan Tahura Ngurah Rai Bali merupakan lokasi yang sangat potensial dalam pemanfaatan di sektor pariwisata, bisnis, dan letaknya yang dekat dengan pemukiman penduduk. Tentu saja hal ini menyebabkan terjadinya tekanan lingkungan akibat adanya limbah domestik. Tidak hanya limbah, alih fungsi lahan juga menyebabkan ekosistem mangrove menjadi rusak. Mengingat peran ekosistem mangrove sangat penting bagi kehidupan makhluk hidup, maka dari itu perlu adanya kajian secara komprehensif untuk mengalisis struktur vegetasi mangrove di Tahura Ngurah Rai Bali.

\section{METODOLOGI}

\subsection{Lokasi dan Waktu Penelitian}

Penelitian ini dilakukan pada bulan Februari-Maret 2017 di Tahura Ngurah Rai, Bali. Lokasi penelitian dibagi menjadi tiga stasiun yaitu di Pantai Mertasari (Stasiun 1), Sungai Mati (Stasiun 2), dan Tanjung Benoa (Stasiun 3) (Gambar 1).



Gambar 1. Lokasi Penelitian di Tahura Ngurah Rai Bali

\subsection{Prosedur Penelitian}

Pengamatan vegetasi mangrove dilakukan pada tiga stasiun penelitian, dimana pada tiap stasiun penelitian ditentukan tiga sub stasiun yang dipasang transek garis dari batas darat sampai dengan batas laut tumbuhnya mangrove. Adapun di dalam transek garis dipasang transek kuadrat (plot) sesuai dengan kategori vegetasi mangrove. Menurut Bengen (2004), transek berukuran $10 \times 10 \mathrm{~m}^{2}$ digunakan untuk pengambilan 
data pohon mangrove, transek 5 x $5 \mathrm{~m}^{2}$ untuk pengambilan anakan mangrove, dan transek 1 x $1 \mathrm{~m}^{2}$ untuk pengambilan data semai mangrove. Pengambilan sampel kualitas lingkungan perairan dan substrat $(\mathrm{pH}$ tanah dan redoks potensial) dilakukan secara in situ ketika kondisi surut agar memudahkan dalam mobilisasi di lokasi penelitian. Sementara itu, analisis fraksi substrat menggunakan metode ayakan saringan bertingkat untuk melihat ukuran butiran substrat. Analisis fraksi substrat dilakukan di Laboratorium Lingkungan Budidaya Perairan, Institut Pertanian Bogor.

\subsection{Analisis Data}

\section{Kerapatan spesies dan kerapatan relatif mangrove}

Kerapatan spesies merupakan nilai yang dapat menggambarkan banyaknya individu suatu jenis per satuan luas (Ghufran dan Kordi 2012).

$$
\mathrm{D} i=\frac{\mathrm{n} i}{\mathrm{~A}}
$$

Keterangan:

$$
\begin{array}{ll}
\mathrm{Di} & : \text { Kerapatan spesies ke- } i\left(\mathrm{ind} / \mathrm{m}^{2}\right) \\
\mathrm{n} i & : \text { Jumlah total tegakan } \mathrm{ke}-i \\
\mathrm{~A} & : \text { Luas area total pengambilan contoh } \\
\left(\mathrm{m}^{2}\right) &
\end{array}
$$

Kerapatan relatif (RDi)

adalah perbandingan antara jumlah tegakan jenis $i$ dan jumlah total tegakan seluruh jenis $\left(\sum \mathrm{n}\right)$.

$$
\mathrm{RD} i=\frac{\mathrm{n} i}{\sum \mathrm{n}} \times 100 \%
$$

\section{Frekuensi spesies dan frekuensi relatif}

Frekuensi (Fi) adalah peluang ditemukannya jenis $i$ dalam plot yang diamati

$$
\mathrm{F} i=\frac{\mathrm{P} i}{\sum \mathrm{p}}
$$

Keterangan:

$$
\begin{array}{ll}
\mathrm{F} i & : \text { Frekuensi spesies ke }-i \\
\mathrm{P} i & : \text { Jumlah plot ditemukannya jenis ke- } i \\
\sum \mathrm{P} & \text { : Jumlah plot pengamatan }
\end{array}
$$

Frekuensi relatif (RFi) adalah perbandingan antara frekuensi spesies $i$ (Fi) dengan jumlah frekuensi untuk seluruh jenis $\left(\sum \mathrm{F}\right)$

$$
\mathrm{RF} i=\frac{\mathrm{P} i}{\sum \mathrm{F}} \times 100 \%
$$

Keterangan:

$\mathrm{RF} i \quad$ : Frekuensi relatif jenis $i$

$\mathrm{Fi} \quad$ : Frekuensi spesies ke- $i$

$\sum \mathrm{F} \quad$ : Jumlah frekuensi untuk seluruh jenis

\section{Penutupan spesies dan penutupan relatif}

Penutupan spesies $(\mathrm{C} i)$ adalah luas penutupan jenis $i$ dalam suatu unit area

$$
\mathrm{C} i=\frac{\sum \mathrm{BA}}{\mathrm{A}}
$$

Keterangan:

$\mathrm{C} i \quad$ : Luas penutupan jenis $i$

BA $: \frac{\pi \mathrm{DBH}}{\mathrm{A}},(\pi=3.1416)$

A : Luas total area pengambilan contoh $\left(\mathrm{m}^{2}\right)$

Penutupan relatif jenis ( $\mathrm{RC} i)$ adalah perbandingan antara luas area penutupan jenis $i(\mathrm{C} i)$ dan total luas area penutupan untuk seluruh jenis $\left(\sum \mathrm{C}\right)$

$$
\mathrm{RC} i=\frac{\mathrm{C} i}{\sum \mathrm{C}} \times 100 \%
$$

Keterangan:

$\mathrm{RC} i$ : Penutupan relatif jenis $i$

$\mathrm{Ci}$ : Luas penutupan spesies $\mathrm{ke}-i$

$\sum \mathrm{C} \quad$ : Total luas area penutupan untuk

seluruh pengaruh

\section{Indeks Nilai Penting (INP)}

Indeks Nilai Penting (INP) adalah analisa secara kuantitatif yang menggambarkan adanya spesies yang mendominasi dalam vegetasi. Perhitungan INP dapat melihat pengaruh suatu spesies mangrove di dalam ekosistem. 
$\mathrm{INP}=\mathrm{RDi}+\mathrm{RFi}+\mathrm{RCi}$

Keterangan:

$\mathrm{RDi}$ : Kerapatan relatif

$\mathrm{RFi}$ : Frekuensi relatif

$\mathrm{RCi}$ : Penutupan relatif

\section{HASIL DAN PEMBAHASAN}

\subsection{Karakteristik Fisika Kimia Perairan}

Pengambilan data kualitas lingkungan perairan meliputi suhu, $\mathrm{pH}$ air, salinitas, dan oksigen terlarut. Berdasarkan hasil pengukuran terdapat terdapat perbedaan nilai pada setiap stasiun (Tabel 1).
Suhu perairan pada setiap stasiun penelitian yaitu $29-29,4{ }^{\circ}$ C. Sesuai dengan Kepmen LH No. 51 (2004), kisaran suhu yang ideal bagi kehidupan mangrove adalah 28 - 32 ${ }^{\circ} \mathrm{C}$. Berdasarkan hasil penelitian, kisaran suhu perairan tidak ada perbedaan secara signifikan. Hal ini terjadi karena kerapatan mangrove yang hampir sama pada setiap stasiun penelitian. Perbedaan suhu perairan disebabkan oleh tinggi rendahnya kerapatan mangrove sehingga memengaruhi intensitas cahaya matahari yang diterima oleh perairan. Pernyataan ini serupa dengan pendapat Poediharajoe et al., (2017) dimana suhu tinggi disebabkan adanya cahaya matahari yang masuk ke dalam kawasan mangrove yang agak terbuka.

Tabel 1. Hasil Pengukuran Parameter Fisika Kimia Perairan

\begin{tabular}{llll}
\hline Parameter & Stasiun 1 & Stasiun 2 & Stasiun 3 \\
\hline Suhu $\left({ }^{\circ} \mathrm{C}\right)$ & $29 \pm 0,68$ & $29,1 \pm 0,81$ & $29,4 \pm 0,57$ \\
pH air & $7,54 \pm 0,32$ & $7,26 \pm 0,15$ & $7,56 \pm 0,11$ \\
Salinitas (\%o) & $20,4 \pm 4,22$ & $13,8 \pm 1,58$ & $20,7 \pm 1,73$ \\
DO $(\mathrm{mg} / \mathrm{l})$ & $4,18 \pm 1,69$ & $2,85 \pm 0,5$ & $4,06 \pm 0,4$ \\
\hline
\end{tabular}

Nilai $\mathrm{pH}$ perairan pada lokasi penelitian adalah 7,26 - 7,56. Sesuai dengan Kepmen LH No. 51 (2004), kisaran pH perairan yang cocok untuk pertumbuhan mangrove adalah 6,5 - 8,5. Salah satu faktor yang mempengaruhi nilai $\mathrm{pH}$ perairan di kawasan mangrove adalah adanya serasah mangrove. Hal ini sesuai dengan pernyataan Adeleke et al., (2017) dimana serasah mangrove yang jatuh terdekomposisi oleh mikroorganisme sehingga menghasilkan detrius yang menyebabkan perairan menjadi asam. Berdasarkan hasil tersebut maka dapat dikatakan bahwa nilai $\mathrm{pH}$ perairan cocok untuk pertumbuhan ekosistem mangrove.

Salinitas adalah kandungan garam dalam perairan yang dapat menentukan kehidupan ekosistem mangrove. Hasil pengukuran salinitas pada stasiun penelitian berkisar antara 13,8 - 20,7 \%o. Terdapat perbedaan kadar salinitas yang signifikan pada stasiun penelitian. Hal ini terjadi karena lokasi penelitian stasiun 1 dan stasiun 3 berada di wilayah pantai sedangkan stasiun 2 berada di wilayah estuari. Lokasi yang berada di estuari menyebabkan adanya pengaruh masukan air tawar dari daratan sehingga salinitas menjadi rendah. Hal ini sesuai dengan pendapat Asri et al., (2015); Geng et $a l .$, (2016), dimana adanya air payau dengan kondisi salinitas yang fluktuatif karena adanya akumulasi air laut dan air tawar. Kepmen LH No. 51 (2004) menyatakan kisaran salinitas pada suatu perairan tidak lebih dari 34 \%o sehingga dapat dikatakan bahwa salinitas cocok untuk pertumbuhan mangrove.

Oksigen terlarut (DO) merupakan indikator kualitas lingkungan perairan yang sangat penting bagi organisme laut. Kandungan DO dibutuhkan dalam proses respirasi dan metabolisme yang selanjutnya menghasilkan energi untuk perkembangbiakan organisme laut (Dubuc et al., 2019). Hasil pengukuran kandungan DO pada stastiun penelitian berkisar antara 2,85 $4,18 \mathrm{mg} / \mathrm{l}$. Tinggi rendahnya nilai DO terjadi karena lokasi penelitian yang dekat dengan pusat kegiatan masyarakat sehingga menghasilkan limbah. Gedan et al., (2017), menyatakan bahwa nilai DO akan rendah apabila limbah masuk ke perairan. Hal ini 
karena DO dimanfaatkan oleh mikroorganisme aerobik dalam proses dekomposisi bahan organik dari limbah. Dalam keadaan tertentu, apabila hal ini terus terjadi maka akan mengganggu kehidupan ekosistem pesisir secara keseluruhan.
Pengamatan parameter fisika kimia substrat pada lokasi penelitian didapatkan bahwa adanya perbedaan nilai $\mathrm{pH}$ tanah, redoks potensial, dan fraksi substrat. Adapun hasil pengamatan disajikan pada Tabel 2 dan Tabel 3.

\subsection{Karakteristik Fisika Kimia Substrat}

Tabel 2. Hasil Pengukuran Parameter Fisika Kimia Substrat

\begin{tabular}{llll}
\hline Parameter & Stasiun 1 & Stasiun 2 & Stasiun 3 \\
\hline pH substrat & $5.36 \pm 0.57$ & $5.23 \pm 0.5$ & $6.04 \pm 0.7$ \\
Redoks Potensial $(\mathrm{mV})$ & 74 & 78 & 92 \\
\hline
\end{tabular}

Redoks potensial (Eh) dan $\mathrm{pH}$ tanah memiliki hubungan erat pada kelarutan dan ketersediaan hara bagi pertumbuhan mangrove (Cyio, 2008). Nilai Eh substrat merupakan suatu besaran potensial listrik yang dapat menggambarkan proses dekomposisi bahan organik dalam substrat yang berlangsung pada keadaan reduksi atau oksidasi (Kurniawan, 2012). Odum (1993) menyatakan nilai $\mathrm{Eh}>+0 \mathrm{mV}$ masuk ke dalam proses oksidasi. Nilai Eh substrat pada stasiun penelitian berkisar $74-92 \mathrm{mV}$ sehingga dapat dikatakan pada kondisi oksidasi terjadi proses dekomposisi bahan organik.

Sementara itu, $\mathrm{pH}$ substrat menggambarkan keseimbangan asam dan basa dalam substrat. Berdasarkan hasil penelitian didapatkan nilai $\mathrm{pH}$ substrat berkisar antara 5,23 - 6,04. Menurut Onrizal dan Kusmana (2008), pH substrat yang layak bagi pertumbuhan mangrove berkisar antara 6 - 7. Nilai pH substrat yang sedikit asam diduga dipengaruhi oleh adanya serasah mangrove yang jatuh ke tanah. Pernyataan ini sesuai dengan pendapat Setiawan (2013), dimana nilai $\mathrm{pH}$ substrat yang asam terjadi karena adanya proses dekomposisi serasah mangrove oleh bakteri pengurai pada substrat yang nantinya akan menghasilkan asam organik sehingga menurunkan $\mathrm{pH}$ substrat.

Substrat merupakan material yang berasal dari proses pelapukan batuan yang tersusun dari organisme, proses kimiawi laut, dan detritus (Prarikeslan, 2016). Pengukuran fraksi substrat dapat menggambarkan kondisi lingkungan perairan untuk pertumbuhan ekosistem pesisir secara keseluruhan. Berdasarkan hasil pengukuran didapatkan bahwa tekstur substrat pada setiap stasiun penelitian memiliki persentase yang berbeda (Tabel 3). Tekstur substrat pasir kasar (pasir) dominan ditemukan pada stasiun 1 (68,9\%) dan stasiun $3(35,1 \%)$. Sementara itu, tekstur substrat halus (lumpur) dominan dijumpai pada stasiun $2(44,2 \%)$. Adanya perbedaan persentase karena karakteristik lokasi penelitian yang berada dekat dengan sungai dan pantai. Tingginya persentase substrat kasar (pasir) pada stasiun 1 dan stasiun 3 karena terletak dekat dengan pantai sehingga adanya pengaruh arus dan gelombang yang dapat mengubah komposisi substrat. Pernyataan ini senada dengan Abdulkarim et al., (2011); Wang et al., (2016) dimana substrat kasar (pasir) umumnya dijumpai pada kondisi perairan yang memiliki arus kuat sedangkan kondisi arus yang tenang lebih banyak ditemukan substrat halus (lumpur). Selain itu juga substrat pasir halus dominan ditemukan pada stasiun 2 karena lokasi yang dekat dengan sungai sehingga pengaruh arus tidak terlalu signifikan terjadi. Menurut Roswaty et al., (2014), butiran substrat lumpur memiliki ukuran yang halus karena kecepatan arus yang melemah pada daerah muara sungai. 
Tabel 3. Fraksi Substrat Dasar di Stasiun Penelitian

\begin{tabular}{lccc}
\hline Substrat (\%) & $\begin{array}{c}\text { Stasiun } \\
\mathbf{1}\end{array}$ & $\begin{array}{c}\text { Stasiun } \\
\mathbf{2}\end{array}$ & $\begin{array}{c}\text { Stasiun } \\
\mathbf{3}\end{array}$ \\
\hline Pasir Halus & 14,9 & 44,2 & 18,9 \\
Pasir Sedang & 8,4 & 20,1 & 26,5 \\
Pasir Kasar & 68,9 & 26,5 & 35,1 \\
Kerikil & 7,8 & 9,2 & 16,7 \\
\hline
\end{tabular}

\subsection{Kerapatan Mangrove}

Berdasarkan hasil pengamatan didapatkan beberapa spesies penyusun zonasi mangrove. Dalam penelitian ini ditemukan 8 (delapan) spesies mangrove yang ditemukan yaitu A. marina, A. corniculatum, $B$. gymnorrhiza, $R$. apiculata, $R$. mucronata, $R$. stylosa, S. alba, dan X. granatum. Hasil penelitian juga menemukan bahwa terdapat perbedaan kerapatan spesies mangrove yang dapat dilihat pada Tabel 4, Tabel 5, dan Tabel 6.

Tabel 4. Kerapatan Mangrove pada Stasiun 1

\begin{tabular}{llll}
\hline \multirow{2}{*}{ Spesies Mangrove } & \multicolumn{3}{c}{ Kerapatan Mangrove (ind/ha) } \\
\cline { 2 - 4 } S. alba & Pohon & Anakan & Semai \\
R. apiculata & 822 & 1467 & 67780 \\
R. mucronata & 722 & 844 & 15556 \\
R. stylosa & - & - & - \\
B. gymnorrhiza & 56 & 444 & 10000 \\
A. corniculatum & 100 & - & 32222 \\
X. granatum & - & - & - \\
A. marina & - & 178 & - \\
\hline
\end{tabular}

Tabel 5. Kerapatan Mangrove pada Stasiun 2

\begin{tabular}{llll}
\hline \multirow{2}{*}{ Spesies Mangrove } & \multicolumn{3}{c}{ Kerapatan Mangrove (ind/ha) } \\
\cline { 2 - 4 } S. alba & 122 & - & Semai \\
R. apiculata & 400 & - & - \\
R. mucronata & 733 & 1822 & 21111 \\
R. stylosa & - & - & 62222 \\
B. gymnorrhiza & 56 & 444 & - \\
A. corniculatum & - & - & - \\
X. granatum & 89 & 356 & - \\
A. marina & - & - & - \\
\hline
\end{tabular}


Tabel 6. Kerapatan Mangrove pada Stasiun 3

\begin{tabular}{llll}
\hline \multirow{2}{*}{ Spesies Mangrove } & \multicolumn{3}{c}{ Kerapatan Mangrove (ind/ha) } \\
\cline { 2 - 4 } & Pohon & Anakan & Semai \\
\hline S. alba & 767 & 1600 & 17778 \\
R. apiculata & 489 & 111 & 15556 \\
R. mucronata & - & - & - \\
R. stylosa & 133 & 444 & 10000 \\
B. gymnorrhiza & 111 & 711 & 11111 \\
A. corniculatum & 122 & 756 & - \\
X. granatum & - & 667 & 12222 \\
A. marina & 78 & - & - \\
\hline
\end{tabular}

Kerapatan spesies mangrove di stasiun 1 pada tingkat pohon dominan ditemukan $S$. alba (822 ind/ha) dan terendah spesies $R$. stylosa (56 ind/ha). Berikutnya pada tingkat anakan, spesies $S$. alba mendominasi (1467 ind/ha) dan terendah dijumpai spesies $X$. granatum (178 ind/ha). Sementara itu, pada tingkat semai spesies $S$. alba paling banyak dijumpai (67780 ind/ha) dan spesies yang jarang ditemukan yaitu $R$. stylosa (10000 ind/ha) (Tabel 4). Menurut Kepmen LH No. 201 (2004) bahwa kerapatan spesies mangrove yang tergolong jarang (rusak) memiliki nilai <1000 ind/ha, baik (sedang) $\geq 1000 \mathrm{ind} / \mathrm{ha}$, dan baik (rapat) $\geq 1500 \mathrm{ind} / \mathrm{ha}$. Jadi dapat dikatakan bahwa kerapatan pohon mangrove termasuk kategori jarang (rusak), sebagian anakan mangrove berada pada kategori baik (sedang) dan sebagian termasuk dalam kategori jarang (rusak), dan semai mangrove masih tergolong baik (rapat).

Kerapatan spesies mangrove di stasiun 2 pada tingkat pohon mangrove ditemukan spesies $R$. mucronata mendominasi (733 ind/ha), diikuti oleh $R$. apiculata (400 ind/ha), dan $S$. alba (122 ind/ha) serta spesies yang paling jarang dijumpai yaitu B. gymnorrhiza (56 ind/ha). Selanjutnya pada tingkat anakan dan semai mangrove, spesies $R$. mucronata paling banyak dijumpai sebesar 1822 ind/ha (anakan) dan 62222 ind/ha (semai) (Tabel 5). Berdasarkan hasil tersebut maka menandakan bahwa pohon mangrove berada pada kategori jarang (rusak) serta kategori anakan dan semai tergolong pada kelompok kategori baik (rapat) dengan nilai $\geq 1500 \mathrm{ind} / \mathrm{ha}$.

Kerapatan spesies mangrove di stasiun 3 pada tingkat pohon, anakan, dan semai mangrove tertinggi dijumpai spesies $S$. alba. Adapun pada kategori pohon kerapatan mangrove $S$. alba (767 ind/ha), diikuti oleh $R$. apiculata (489 ind/ha), dan $R$. Stylosa (133 ind/ha) serta spesies yang paling sedikit ditemukan yaitu A. marina (78 ind/ha). Berikutnya pada tingkat anakan ditemukan sebesar 1600 ind/ha, dan kategori semai sebesar 17778 ind/ha. Di lain pihak, pada tingkat anakan mangrove $R$. apiculata paling jarang dijumpai dengan nilai 111 ind/ha dan $R$. stylosa sebesar $10000 \mathrm{ind} / \mathrm{ha}$ pada tingkat semai mangrove. Berdasarkan hasil tersebut maka dapat dikatakan bahwa pohon mangrove berada pada kategori jarang (rusak) serta kategori anakan dan semai tergolong pada kelompok kategori baik (rapat) dengan nilai $\geq$ $1500 \mathrm{ind} / \mathrm{ha}$.

\subsection{Indeks Nilai Penting}

Perhitungan Indeks Nilai Penting (INP) dilakukan menggunakan analisis vegetasi yang meliputi total hasil dari kerapatan relatif, frekuensi relatif, dan penutupan relatif. Nilai INP memiliki kisaran antara 0 - 300 dan dapat dilihat pada Gambar 2. 


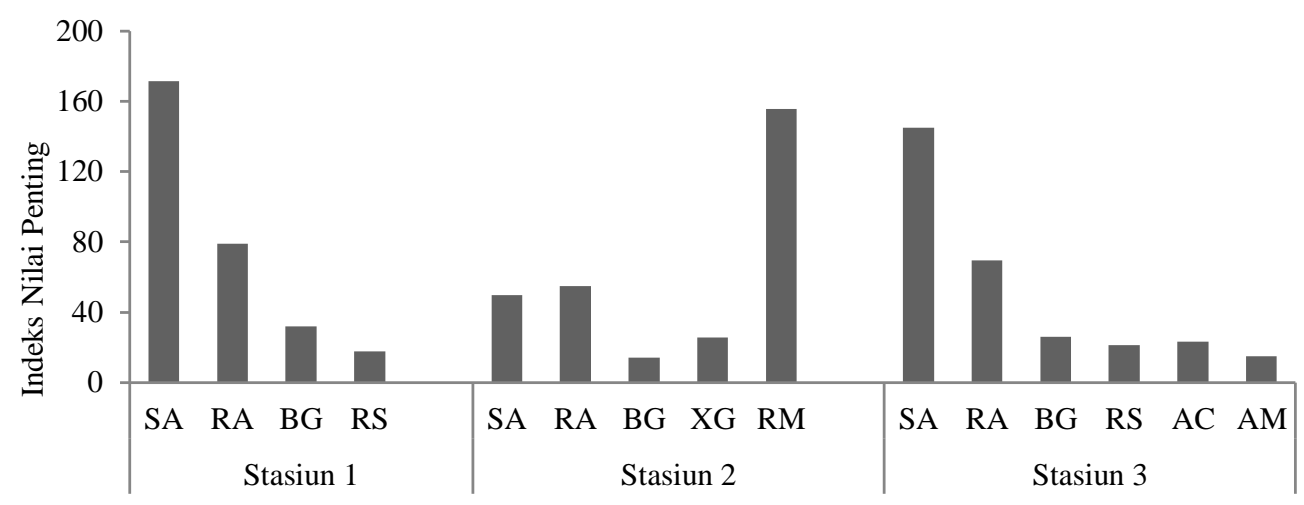

Gambar 2. Indeks Nilai Penting Mangrove Pada Setiap Stasiun Penelitian

$\begin{array}{ll}\text { Keterangan } \\ \text { AC } & \text { : Aegiceras corniculatum } \\ \text { AM } & \text { : Avicennia marina } \\ \text { BG } & \text { : Bruguiera gymnorrhiza } \\ \text { RA } & \text { : Rhizophora apiculata }\end{array}$

Pertumbuhan ekosistem mangrove dapat dilihat berdasarkan kondisi vegetasi yang menggambarkan tinggi rendanya fungsi suatu spesies terhadap suatu ekosistem. Kondisi ini dapat dianalisis dengan menggunakan analisis INP. Nilai INP yang tinggi menggambarkan spesies tertentu adaptif terhadap kondisi lingkungan. Sebaliknya, rendahnya nilai INP mengindikasikan bahwa spesies tersebut kurang mampu bersaing dengan lingkungan sekitar. Akbar et al., (2016) memaparkan tingginya nilai INP yang berada di suatu lokasi menandakan bahwa pertumbuhan mangrove baik dan adaptif terhadap kondisi lingkungan yang ada.

Hasil pengamatan yang dilakukan menunjukkan bahwa jenis $S$. alba dan $R$. mucronata mendominasi di lokasi pengamatan. Jenis mangrove yang dominan ditemukan pada Stasiun 1 yaitu $S$. alba $(171,63)$ dan terendah ditemukan jenis $R$. stylosa (17,78). Selanjutnya, jenis $R$. mucronata dominan ditemukan pada Stasiun $2(155,58)$ dan jenis $B$. gymnorrhiza memiliki nilai INP yang paling rendah diantara seluruh spesies yang ditemukan $(13,91)$. Sementara itu, pada Stasiun 3 jenis $S$. alba paling banyak ditemukan $(145,13)$ dan jenis A. marina paling jarang ditemukan $(15,06)$.

Penyebaran jenis $S$. alba dan $R$. mucronata meningkat apabila lokasi

$\begin{array}{ll}\text { RM } & \text { : Rhizophora mucronata } \\ \text { RS } & \text { : Rhizophora stylosa } \\ \text { SA } & \text { : Sonneratia alba } \\ \text { XG } & \text { : Xylocarpus granatum }\end{array}$

mengarah ke daratan pengaruh ombak yang lemah, substrat lumpur yang tinggi, dan lokasi penelitian yang berada di wilayah estuari sehingga tingkat adaptasi mangrove terhadap lingkungan menjadi lebih tinggi karena melemahnya tekanan lingkungan. Pernyataan ini didukung oleh Darmadi dan Ardhana (2010); Prabu dan Gokul (2017), dimana mangrove tumbuh pada wilayah pesisir dengan ombak yang tenang dan substrat lumpur yang kaya akan bahan organik.

\subsection{Sebaran Mangrove dengan Karakteristik Lingkungan}

Hasil Principal Component Analysis (PCA) yang didapatkan menggambarkan bahwa data terkait dengan kualitas lingkungan biofisik pada lokasi penelitian berada pada sumbu F1 dan F2 dengan keragaman total sebesar 65,99\% (Gambar 3).

Sumbu 1 (F1) menerangkan keragaman data sebesar 44,85\% yang dipengaruhi nilai suhu, salinitas, oksigen terlarut, dan $\mathrm{pH}$ air yang tinggi pada stasiun 1 dan stasiun 3. Lokasi pengambilan data yang terletak di wilayah pesisir dan estuari menyebabkan parameter lingkungan yang diamati memiliki perbedaan nilai. Adanya perbedaan nilai disebabkan adanya percampuran air tawar dan tinggi rendahnya curah hujan. 


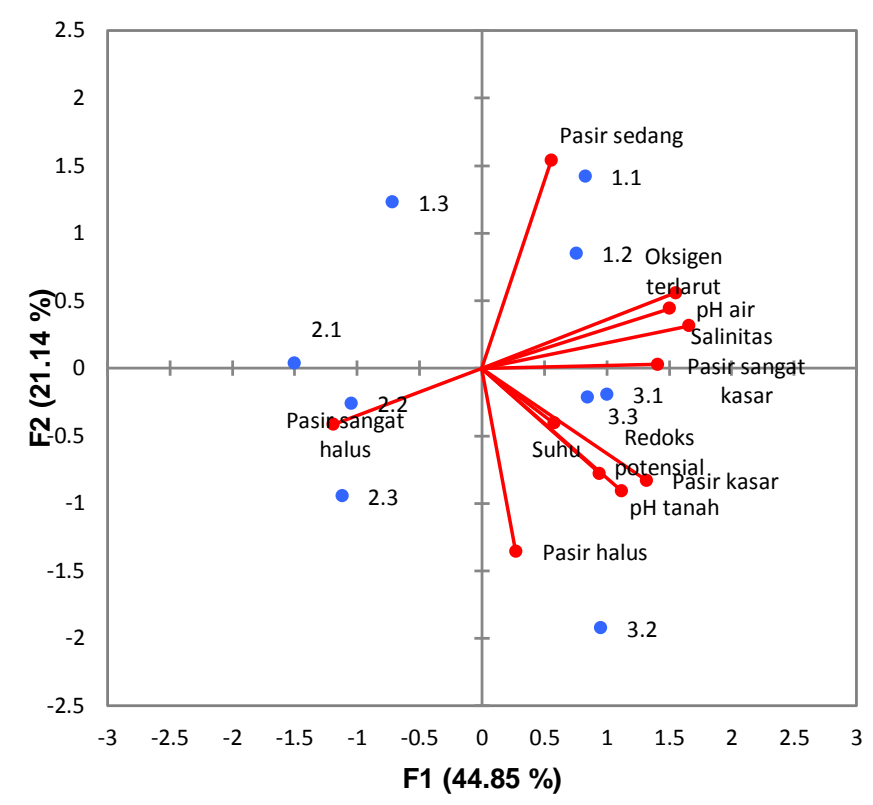

Gambar 3. Analisis PCA antara Lokasi Penelitian dengan Lingkungan

Sumbu 2 (F2) menerangkan keragaman data sebesar 21,14 \% yang dicirikan oleh substrat pasir sedang dan pasir halus yang tinggi pada stasiun 2 (Gambar 3). Lokasi penelitian yang berada di wilayah estuari menyebabkan turbulensi arus lemah sehingga lebih banyak ditemukan substrat halus (lumpur). Hal ini senada dengan
Kamaruzzaman et al., (2002); Nugroho dan Basit (2014); Eddy dan Roman (2016), dimana butiran substrat kasar lebih dominan ditemukan pada perairan dengan arus yang kuat sedangkan butiran substrat halus sangat mendominasi pada kondisi perairan dengan arus yang tenang.

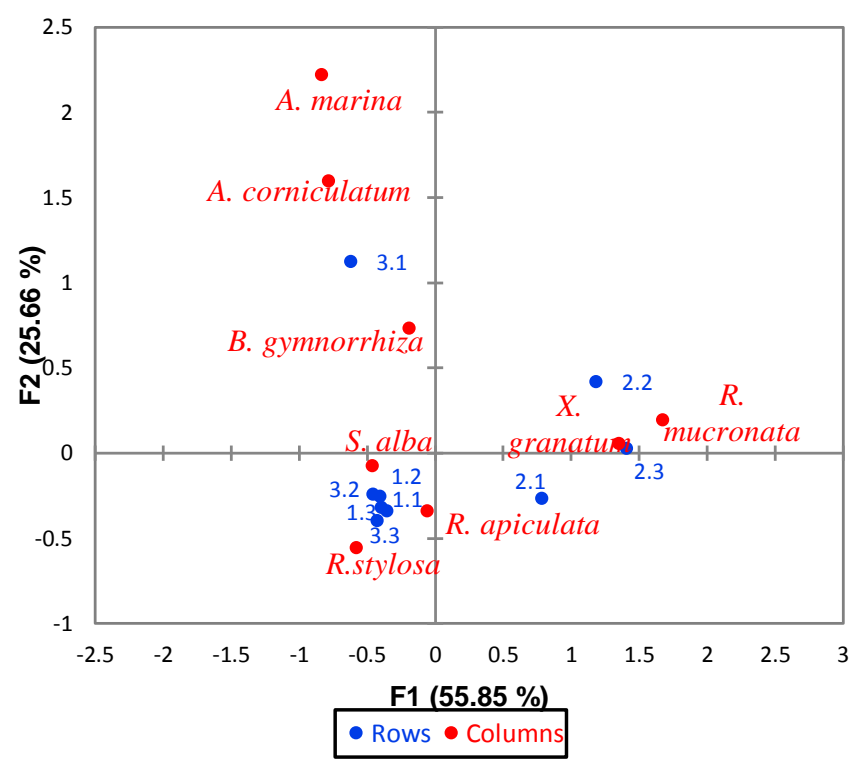

Gambar 4. Analisis CA antara Lokasi Penelitian dengan Mangrove

Hasil Correspondence Analysis (CA) menunjukkan bahwa terdapat korelasi antara karakteristik lokasi penelitian dengan spesies mangrove. Hasil CA berada pada sumbu F1 dan F2 dengan keragaman data sebesar 81,51 \% (Gambar 4). Sumbu 1 (F1) menjelaskan 
keragaman data sebesar 55,85\% dimana spesies $R$. mucronata dan $X$. granatum dominan ditemukan di stasiun 2 yang dicirikan jenis substrat halus (lumpur) (Gambar 3). Hal ini sesuai dengan pendapat Robertson and Alongi (2016); Warsidi dan Endayani (2017), dimana pertumbuhan $R$. mucronata dan $X$. granatum optimal pada kondisi arus yang tenang dan substrat lumpur yang kaya bahan organik.

Sumbu 2 (F2) menerangkan keragaman data sebesar $25.66 \%$ dimana A. marina dan Aegiceras corniculatum dijumpai pada Stasiun 3 yang dicirikan oleh suhu perairan yang tinggi. Jenis A. marina yang jarang ditemukan Stasiun 3 diduga karena suhu yang tidak mendukung pertumbuhan kedua jenis ini. Suhu ideal untuk pertumbuhan jenis $A$. marina berkisar antara $18-20{ }^{\circ} \mathrm{C}$ dan apabila suhu lebih tinggi maka akan mengganggu pertumbuhannya (Aksornkoae, 1993). Selain itu, tingginya suhu perairan karena adanya penebangan pohon mangrove sehingga cahaya matahari langsung menembus ke perairan.

\section{SIMPULAN DAN SARAN}

\subsection{Simpulan}

Terdapat 8 (delapan) spesies mangrove di kawasan Tahura Ngurah Rai Bali. Secara berturut - turut, kerapatan mangrove tertinggi yaitu $S$. alba (122 - 822 ind/ha), diikuti oleh $R$. mucronata (733 ind/ha), $R$. apiculata (400 - $722 \mathrm{ind} / \mathrm{ha}$ ), R. stylosa (56 - $133 \mathrm{ind} / \mathrm{ha}$ ), A. corniculatum (122 ind/ha), B. gymnorrhiza (56 - $111 \mathrm{ind} / \mathrm{ha}), X$. granatum (89 ind/ha), dan A. marina (78 ind/ha). Spesies $S$. alba, $R$. apiculata, dan $R$. mucronata dominan ditemukan pada kondisi substrat halus (lumpur) sedangkan spesies $A$. marina jarang dijumpai karena kondisi suhu perairan yang tidak mendukung pertumbuhannya. Berdasarkan hasil penelitian dapat dikatakan bahwa kondisi ekosistem mangrove tergolong jarang (rusak) karena nilai kerapatan mangrove $<1000 \mathrm{ind} / \mathrm{ha}$.

\subsection{Saran}

Adanya penelitian lanjutan tentang pengaruh limbah logam berat terhadap penurunan kualitas lingkungan biofisik dan ekosistem mangrove dan perlu adanya penelitian lanjutan pada lokasi yang sama namun pengambilan data dilakukan pada waktu yang berbeda agar informasi yang dihasilkan menjadi informasi ilimah dalam upaya mendukung keberhasilan perencaanan dan pengelolaan mangrove di Tahura Ngurah Rai Bali.

\section{DAFTAR PUSTAKA}

Abdulkarim, R., Akintoye, A.E., Oguwuike, I.D., Imhansoeleva, T.M., Philips, I.M., Ruth, F.B., Olubukola, S.O., Rasheed, J.O., and Banji, A.O. 2011. Sedimentological Variation in Beach Sediments of the Barrier bar Lagoon Coastal System, South-Western Nigeria. Nature and Science. 9(9):19-26.

Adeleke, R., Nwangburuka, C., Oboirien, B. 2016. Origins, roles and fate of organic acids in soils: A review. South African Journal of Botany. 108: 393-406.

Aksornkoae, S. 1993. Ecology and Management of Mangrove. Bangkok (TH): IUCN.

Akbar, N., Baksir, A., Tahir, I., Arafat, D. 2016. Struktur komunitas mangrove di Pulau Mare, Kota Tidore Kepulauan, Maluku Utara, Indonesia. Jurnal Depik. 5(3): 133-142.

Ashton, E.C., Macintosh, D., Hogarth, P.J. 2003. A Baseline Study of the Diversity and Community Ecology of Crab and Molluscan Macrofauna in the Sematan Mangrove Forest, Sarawak, Malaysia. Journal of Tropical Ecology. 19. 127142.

Asri, F.E., Zidane, H., Maanan, M., Tamsouri, M., Errhif, A. 2015. Taxonomic diversity and structure of the molluscan fauna in Oualidia Lagoon (Moroccoan Atlantic Coast). Environmental Monitoring and Assessment. 187: 1-10.

Bengen, D.G. 2004. Pedoman Teknis Pengenalan dan Pengelolaan Ekosistem Mangrove. Bogor (ID): PKSPL-IPB. 
Cyio, M.B. 2008. Efektivitas bahan organik dan tinggi genangan terhadap perubahan Eh, $\mathrm{pH}$, dan status $\mathrm{Fe}, \mathrm{P}, \mathrm{Al}$ terlarut pada tanah ultisol. Jurnal Agroland. 15(4): 257-263.

Darmadi, A.A.K., Ardhana, I.P.G. 2010. Komposisi Jenis - Jenis Tumbuhan Mangrove di Kawasan Hutan Perapat Benoa Desa Pemogan, Kecamatan Denpasar Selatan, Kodya Denpasar, Propinsi Bali. Jurnal Ilmu Dasar. 11(2): $167-171$.

Dubuc, A., Baker, R., Marchand, C., Waltham, N.J., Sheaves, M. 2019. Hypoxia in mangroves: occurrence and impact on valuable tropical fish habitat. Biogeosciences. 16: 3959-3976.

Eddy, E.N., Roman, C.T. 2016. Relationship between epibenthic invertebrate species assmblaged and environmental variables in Boston Harbor's Intertidal Habitat. Northeastern Naturalist. 23(1): 45-6.

Gedan, K.R., Altieri, A.H., Feller, I., Burrell, R., Breitburg, D. 2017. Community composition in mangrove ponds with pulsed hypoxic and acidified conditions. Ecosphere. 8(12): 1-18.

Geng, X., Boufadel, M.C., Jackson, N.L. 2016. Evidence of salt accumulation in beach intertidal zone due to evaporation. Scientific Reports. 6: 1-6.

Ghufran, H.M., Kordi, K. 2012. Ekosistem Mangrove: Potensi, Fungsi, dan Pengelolaan. Jakarta (ID): Rineka Cipta.

Kamaruzzaman, B.Y., Shazili, N.A.M., Lokman. M. 2002. Particle size distribution in the bottom sediments of the Kemaman River Estuarine System, Terengganu, Malaysia. Journal of Tropical Agriculture Science. 25(2): $149-155$.

Kurniawan, A. 2012. Penyakit Akuatik. Pangkal Pinang (ID): UBB Press.

[MENLH] Menteri Negara Lingkungan Hidup. 2004. Keputusan Kantor Menteri Negara Lingkungan Hidup No. Kep
51/MENLH/1/2004 tentang Pedoman Penetapan Baku Mutu Lingkungan. Jakarta (ID): Menteri Negara Lingkungan Hidup.

[MENLH] Menteri Negara Lingkungan Hidup. 2004. Keputusan Kantor Menteri Negara Lingkungan Hidup No. Kep 201/MENLH/1/2004 tentang Kriteria Baku dan Pedoman Penentuan Kerusakan Mangrove. Jakarta (ID): Menteri Negara Lingkungan Hidup.

Nugroho, S.H., Basit, A. 2014. Sebaran sedimen berdasarkan analisis ukuran butir di Teluk Weda, Maluku Utara. Jurnal Ilmu dan Teknologi Kelautan Tropis. 6(1): 229-240.

Onrizal., Kusmana, C. 2008. Studi ekologi hutan mangrove di Pantai Timur Sumatera Utara. Jurnal Biodiversitas. 9 (1): 25-29.

Poediraharsjoe, E., Djoko, M., Frita, K.W. 2017. Penggunaan Principal Component Analysis dalam distribusi spasial vegetasi mangrove di Pulau Utara Pemalang. Journal of Forest Science.29-42.

Prabu, E., Gokul, S. 2017. Mangrove: An incredible ecosystem for sustainable fisheries. Journal of Aquaculture in the Tropics. 32(3): 397-411.

Prarikeslan W. 2016. Oseanografi. Jakarta: Penerbit Kencana.

Robertson, A.I., Alongi, D.M. 2016. Massive turnover rates of fine root detrital carbon in tropical Australian mangroves. Oecologia. 180: 841-851.

Roswaty, S., Muskananfola, M.R., Purnomo, P.W. 2014. Tingkat Sedimentasi di Muara Sungai Wedung Kecamatan Wedung, Demak. Journal of Maquares. 3(2): 129 - 137.

Setiawan, H. 2013. Status ekologi hutan mangrove pada berbagai tingkat ketebalan. Jurnal Penelitian Kehutanan Wallacea. 2 (2): 104-120.

Wang, X.Y., Xie, W.M., Zhang, D., He, Q. 2016. Wave and vegetation effects on 
flow and suspended sediment characteristics: A flume study. Estuarine Coastal and Shelf Science. 182: 1-11.

Warsidi., Endayani, S. 2017. Komposisi Vegetasi Mangrove Di Teluk Balikpapan Provinsi Kalimantan Timur. Jurnal Agrifor. 16(1): 115-124. 